
Not for reproduction, distribution or commercial use.

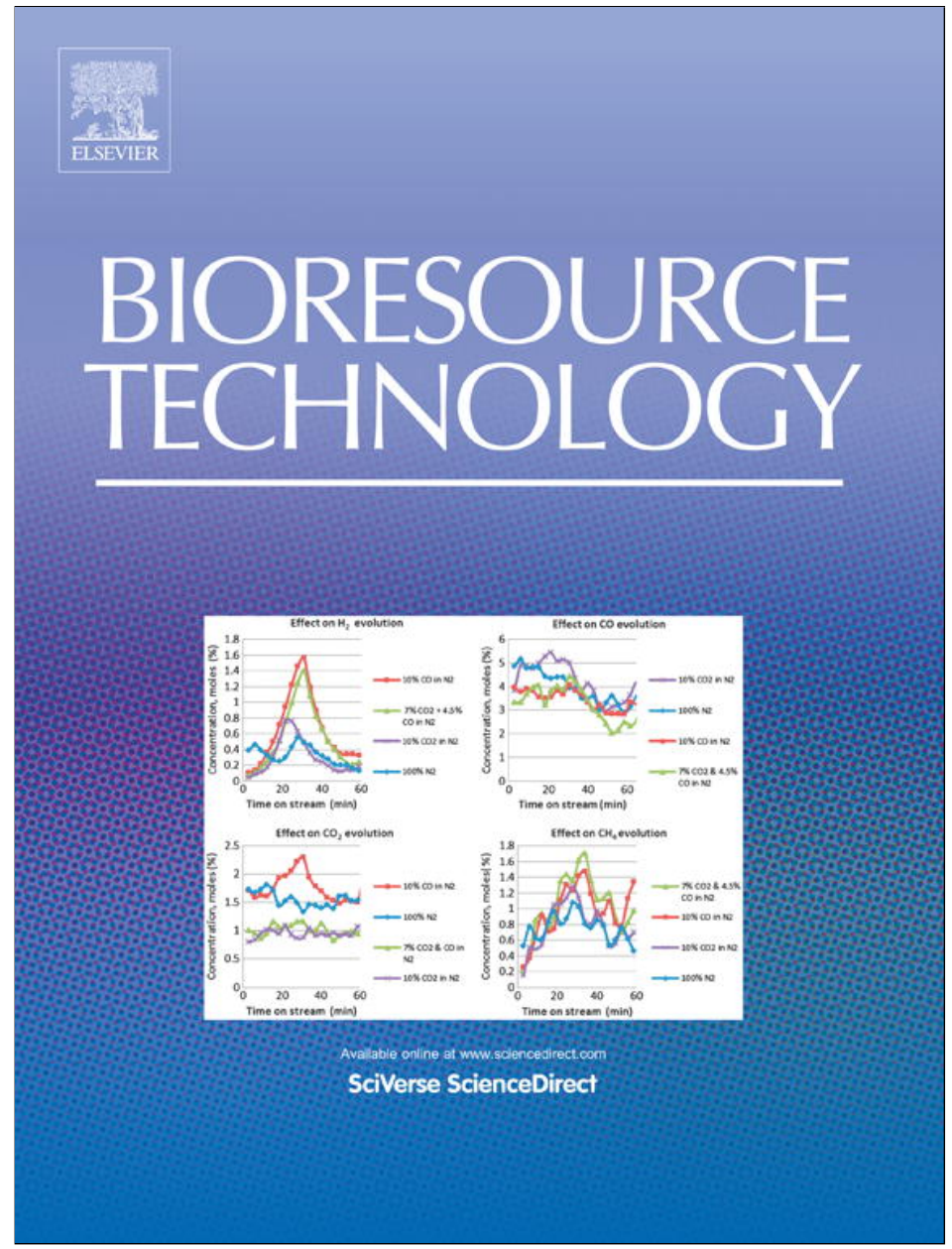

This article appeared in a journal published by Elsevier. The attached copy is furnished to the author for internal non-commercial research and education use, including for instruction at the authors institution and sharing with colleagues.

Other uses, including reproduction and distribution, or selling or licensing copies, or posting to personal, institutional or third party websites are prohibited.

In most cases authors are permitted to post their version of the article (e.g. in Word or Tex form) to their personal website or institutional repository. Authors requiring further information regarding Elsevier's archiving and manuscript policies are encouraged to visit:

http://www.elsevier.com/authorsrights 


\title{
Bioethanol production from pretreated Melaleuca leucadendron shedding bark - Simultaneous saccharification and fermentation at high solid loading
}

\author{
Ibrahim Nasser Ahmed ${ }^{a}$, Phuong Lan Tran Nguyen ${ }^{a}$, Lien Huong Huynh ${ }^{\mathrm{b}}$, Suryadi Ismadji ${ }^{\mathrm{c}}$, Yi-Hsu Ju ${ }^{\mathrm{a}, *}$ \\ ${ }^{a}$ Department of Chemical Engineering, National Taiwan University of Science and Technology, 43 Keelung Rd., Sec. 4, Taipei 106-07, Taiwan \\ ${ }^{\mathrm{b}}$ Department of Chemical Engineering, Can Tho University, 3-2 Street, Can Tho City, Viet Nam \\ ${ }^{\mathrm{c}}$ Department of Chemical Engineering, Widya Mandala Surabaya Catholic University, Kalijudan 37, Surabaya 60114, Indonesia
}

\section{H I G H L I G H T S}

- Paper bark tree shedding bark has higher glucan component.

- SCW at mild temperature is efficient for pretreatment of shedding bark.

- High ethanol production $(63.2 \mathrm{~g} / \mathrm{L})$ was achieved at $0.25 \mathrm{~g} / \mathrm{mL}$ solid loading.

- High ethanol (43.7 g/L) and yield (91.25\%) were obtained at $0.15 \mathrm{~g} / \mathrm{mL}$ solid loading.

\section{A R T I C L E I N F O}

\section{Article history:}

Received 1 January 2013

Received in revised form 22 February 2013

Accepted 25 February 2013

Available online 14 March 2013

\section{Keywords:}

Paper bark tree

Bioethanol

Subcritical water

Saccharomyces cerevisiae

\begin{abstract}
A B S T R A C T
Bioethanol production from the shedding bark of Melaleuca leucadendron (Paper-bark Tree, PBT) was studied using subcritical water $(\mathrm{SCW})$ pretreatment at various severities $\left(S_{0}\right)$. High ethanol production was attained by implementing a factorial design on three parameters $\left(S_{0}\right.$, solid loading and enzyme loading) in simultaneous saccharification and fermentation (SSF) mode. Ethanol concentration of $63.2 \mathrm{~g} \mathrm{~L}^{-1}$ corresponding to ethanol yield of $80.9 \%$ were achieved from pretreated biomass $\left(S_{\mathrm{o}}=2.37\right)$ at $0.25 \mathrm{~g} \mathrm{~mL}^{-1}$ solid and $16 \mathrm{FPU} \mathrm{g}^{-1}$ glucan enzyme loadings. Similarly at $0.15 \mathrm{~g} \mathrm{~mL}^{-1}$ solid loadings both high ethanol concentration (43.7 $\mathrm{g} \mathrm{L}^{-1}$ ) and high ethanol yield (91.25\%) were achieved. Regression analysis of experimental results shows that all process parameters had significant role on maximum ethanol production, glucose solubility, ethanol yield and ethanol volumetric productivity. SSF of SCW treated PBT biomass is economically feasible for production of bioethanol.
\end{abstract}

(c) 2013 Elsevier Ltd. All rights reserved.

\section{Introduction}

The world is facing sustaining high oil price and progressive depletion of non-renewable fuel resources, while energy consumption keeps growing. In addition, the intensive use of fossil fuels has led to increasing release of polluting gasses into the atmosphere, which has caused change in global climate. Increasing concerns about climate change and energy security have motivated the search for alternative energy (Valentine, 2011). The growing interest in gasoline substituting fuels has boosted bio-ethanol production worldwide from 12 to 19.5 billion gallons in the period of 2005-2009, with the USA and Brazil being the two largest producers representing $54 \%$ and $34 \%$ of total production, respectively (RFA, 2010). Ethanol use in 2011 reduced tailpipe $\mathrm{CO}_{2}$-equivalent emissions by 25.3 million metric tons. That is equivalent to the

\footnotetext{
* Corresponding author. Tel.: +886 2 27376612; fax: +8862 27376644.

E-mail address: yhju@mail.ntust.edu.tw (Y.-H. Ju).
}

emissions of 4 million vehicles. Moreover the most current measurement of ethanol's energy balance shows a positive 1.7-2.3 score, meaning ethanol is providing twice the energy it took to produce (RFA, 2012).

Most of the ethanol produced today is from starch and sugar producing crops (RFA, 2012). The use of this type of biomass has been increasingly debated due to its impact on food supply as well as for environmental reasons. Therefore, complex (lignocellulosic) biomass has been put forward as a feasible alternative due to its abundance in nature and the large quantities generated as waste from agricultural activities, its higher cellulose content and compositional uniformity. Moreover, tree possesses a lignocellulosic energy conversion factor of 16 (compared to 1 and 8 for corn and sugarcane, respectively), and can be grown on marginal land, thereby minimizing encroachment on land for growing food crops (Fenning et al., 2008). Thus the conversion of lignocellulosic biomass to fuel offers potential economical and environmental advantage. Melaleuca leucadendron (paper-bark tree, PBT) is easily 
recognized by its odd whitish bark, which splits and peels in many papery layers. The tree continually sheds its outer bark and exposes the whiter inner part. The native range of PBT is along the coast of eastern Australia from Sydney northward. It is native also in New Caledonia, Papua, New Guinea, and Irian Jaya. PBT has high adaptability and grows well in poor soil, dry and submerged environments, swampy ground and on creek banks, and even on hillsides if ground water remains close to the surface. In its native habitat, PBT grows to $82 \mathrm{ft}$ tall and is typically found in almost pure stands or with a few associates, such as Casuarina glauca, Eucalyptus robusta, and E. tereticornis. And in the continental United States, PBT is naturalized on a significant scale in Florida and plantations in Hawaii and California (Geary and Woodall, 1990). The wood is a suitable timber for such uses as pulp and cabinetry; the bark has potential uses as an amendment to plant potting mixes and in packaging and insulation. The entire tree can be used as a biomass fuel (Geiger, 1981). Its leaves and fruits are rich in essential oil (cajuput oil), and has been used as a perfume and a popular remedy (Guenther, 1950). The shedding bark of PBT was used as feedstock for bioethanol production in this study.

Pretreatment of lignocellulose biomass is crucial for achieving effective hydrolysis of substrates since enzymatic hydrolysis of native lignocelluloses produces less than $20 \%$ glucose from the cellulose fraction (Zhang and Lynd, 2004). Processing shortages such as long residence time, high energy demand, high cost, and environment pollution exist in current biological, physical, chemical and physicochemical pretreatment methods (Shill et al., 2011). Therefore, the major concern in lignocellulose conversion is overcoming biomass recalcitrance through pretreatment while still maintaining a green and energy efficient process (Lee et al., 2009). Hot compressed water (HCW) for autohydrolysis or hydrothermal processing has attracted considerable attention. The advantages are: corrosion problems are limited, no sludge is generated, reduces the need for neutralization and conditioning chemicals since neither acid nor base is added, simple to implement, capital and operational costs are low, and cellulose is not significantly degraded under normal operating conditions (Liu 2010; Mosier et al., 2005). HCW has been shown to effectively pretreat lignocellulosic biomass by partially hydrolyzing the hemicelluloses and disrupting the lignin and cellulose structures, thus increasing the surface area (Hendriks and Zeeman, 2009). However, HCW under severe conditions may generate inhibitors for enzymatic hydrolysis and fermentation, such as vanilline, syringaldehyde, furfural and 5-hydroxy methyl furfural (HMF) (Carolina et al., 2011). The properties of HCW change with temperature and density (Kruse and Dinjus, 2007). Below the critical temperature or at very high pressures (subcritical condition) the ionic product is up to three orders of magnitude higher than that at ambient conditions, which means that water is an acid/base catalyst precursor (Alenezi et al., 2009). Also the dielectric constant being much higher in the subcritical than in the supercritical region of HCW, hence it favors ionic reaction. This region is used for various synthesis reactions but also for degradation reactions such as biomass liquefaction (Kruse and Dinjus, 2007). Subcritical water (SCW), which is defined as $\mathrm{HCW}$ at temperatures between 100 and $374{ }^{\circ} \mathrm{C}$ under high pressure, has been used for hydrolysis of lignocellulose biomass ( $\mathrm{Lu}$ and Saka, 2010).

The production of ethanol from pretreated lignocellulose material can be carried out either in a two-step separate hydrolysis and fermentation (SHF) or in a single stage simultaneous saccharification and fermentation (SSF). The products formed during the hydrolysis step in an SHF process, such as cellobiose and glucose, inhibit the cellulase enzyme as well as the fermenting microorganisms. However, in SSF glucose produced from hydrolysis is simultaneously metabolized by microorganism, thereby alleviating problems caused by product inhibition (Alfani et al., 2000).
Moreover, the SSF process has other advantages such as reduced operational costs, lower enzyme requirement and increased productivity (Chen et al., 2007).

Conversion of lignocellulosic materials to monomeric sugars and finally to ethanol must be performed at low cost, while still achieving high yield. Hence the type of pretreatment and its aftermath on the overall process are important (Mosier et al., 2005). The two important variables affecting the economic features of bioethanol manufacturing are solid and enzyme loadings. A threshold of economical profitable bio-ethanol production, which is 4-5 volume percent in a fermentation broth (Manzanares et al., 2011), demands the utilization of media containing an initial solid loading of at least $0.15 \mathrm{~g} \mathrm{~mL}^{-1}$ (on dry basis). However, high solid loading creates an environment in which practically no free water exists in the pretreated material which may result in limited cellulose conversion in enzymatic hydrolysis or in SSF, owing to mass transfer limitation (Romaní et al., 2012).

The objective of this work was production of bioethanol, which will meet an economic profitable concentration limit, from SCW pretreated PBT shedding bark. In this study a $3^{3}$ factorial design was implemented to investigated the effects of SCW pretreatment; solid loading and enzyme loading which are believed to play important roles in selected variables (ethanol concentration, ethanol yield, volumetric yield and glucan solubilization) in SSF.

\section{Methods}

\subsection{Raw material}

Shedding bark of PBT was collected from experimental farm of National Taiwan University, Da'an District, Taipei, Taiwan. The location of the farm is N $2500^{\prime} 59.40^{\prime \prime}$; E $12132^{\prime} 25.1^{\prime \prime}$. The air dried bark was milled to pass $8 \mathrm{~mm}$ screen, and stored in a dessicator before use.

\subsection{Pretreatment}

There are three main parts in the equipment for pretreatment: reactor, heater and control devices. The reactor is made of stainless steel with a total inner volume of about $200 \mathrm{~mL}$. It is $25 \mathrm{~mm}$ thick and can withstand an estimated maximum operation pressure of $100 \mathrm{MPa}$. The reactor is equipped with a thermocouple and a pressure gage. The process was run under batch mode with magnetic stirring (50 rpm). For SCW pretreatment, nitrogen gas (99.9\% purity) purchased from Dong-Xing Company (Taiwan) was used to maintain constant pressure (20 bar) in the reactor. Dried and milled bark $(10 \mathrm{~g})$ and deionized (DI) water $(100 \mathrm{~mL})$ was put in the reactor. The suspension was heated to the desired temperature $\left(120-180^{\circ} \mathrm{C}\right)$ and kept at that temperature for a predetermined time $(15,30$ or $60 \mathrm{~min})$. The subcritical condition was terminated by venting vapor in the reactor. The reactor was then cooled to room temperature and the slurry collected from the reactor was filtered. The filtrate was analyzed for its monomeric sugar (glucose, xylose and galactose) and inhibitors (5-hydroxymethylfurfural, furfural and phenols) contents. The collected solid was washed with DI water and kept at $4{ }^{\circ} \mathrm{C}$.

The extent of SCW treatment can be expressed in terms of severity $\left(S_{0}\right)$, defined as the logarithm of the severity factor $R_{\mathrm{o}}$ (Romaní et al., 2010), which was calculated using the expression:

$$
\begin{aligned}
S_{0} & =\log R_{0}=\log \left[R_{0} \text { heating }+R_{0} \text { cooling }\right] \\
& =\log \left[\int_{0}^{t_{\max }} \frac{T_{(t)}-T_{R e f}}{\omega} \cdot d_{t}+\int_{t_{\max }}^{t_{F}} \frac{T_{(t)}^{\prime}-T_{R e f}}{\omega} \cdot d_{t}\right]
\end{aligned}
$$


According to this equation, $S_{\mathrm{o}}$ includes the combined effects of temperature and reaction time. In Eq. (1), $t_{\max }(\mathrm{min})$ is the time needed to achieve $T_{\max }\left({ }^{\circ} \mathrm{C}\right), t_{F}(\min )$ is the time needed for the whole heating-cooling period, whereas $T_{(t)}$ and $T_{(t)}^{\prime}$ represent the temperature profiles in heating and cooling, respectively. Calculations were made assuming the values reported in literature for $\omega$ $\left(14.75^{\circ} \mathrm{C}\right)$ and $T_{R e f}\left(100{ }^{\circ} \mathrm{C}\right)$.

\subsection{Chemical composition analysis}

Compositions of carbohydrates and lignin of SCW treated and untreated shedding barks were determined using the standard NREL method as described by Sluiter et al. (2011). In brief the sample $(300 \mathrm{mg})$ was treated with $\mathrm{H}_{2} \mathrm{SO}_{4}(3 \mathrm{~mL}, 72 \%)$ in a water bath $\left(30^{\circ} \mathrm{C}\right.$ ) and incubated for $1 \mathrm{~h}$ followed by diluting the acid to $4 \%$ by adding $84 \mathrm{~mL} \mathrm{DI}$ water, autoclaved for $1 \mathrm{~h}$ at $121^{\circ} \mathrm{C}$. The hydrolysis solution was vacuum filtered using filtering crucible. Acid insoluble lignin in the residue was determined after ashing in ramping furnace for $24 \mathrm{~h}$. Acid soluble lignin and the major structural components (glucan, xylan, and galactan) were analyzed from the hydrolysis filtrate. The liquid phase was passed through a $0.22 \mu \mathrm{m}$ PVDF syringe filter (Testhigh), then analyzed for monomeric glucose, xylose and galactose using a HPLC (Jasco, Japan) equipped with a Jasco 830-RI Intelligent RI detector and a Cosmosil sugar-D column ( $4.6 \mathrm{~mm}$ I.D. $\times 250 \mathrm{~mm}$ ). Acetonitrile: water $(80: 20 \mathrm{v} / \mathrm{v})$ was used as the mobile phase at a flow rate of $1.0 \mathrm{~mL} \mathrm{~min}^{-1}$. Similarly sugars in the prehydrolysate (pretreatment liquor) and SSF product were analyzed using the same HPLC system.

The Liquid fraction was autoclaved with $4 \%$ sulfuric acid for $1 \mathrm{~h}$ at $121^{\circ} \mathrm{C}$ to break down oligomeric sugars into monomeric ones. Sugar standards with known concentrations were also autoclaved for the same time and at the same acid concentration to calibrate hydrolysis loss factors. The total amount of oligomeric sugars in the liquid sample was then calculated as: determined by gas chromatography (GC-14B, Shimadzu, Japan) with a flame ionization detector. Other conditions of operation were: Nitrogen as the mobile phase $\left(30 \mathrm{~mL} \mathrm{~min}^{-1}\right)$, column temperature $40^{\circ} \mathrm{C}$, injector temperature $200^{\circ} \mathrm{C}$, and detector temperature $250^{\circ} \mathrm{C}$. Injection volume was $1 \mu \mathrm{L}$. The concentration of ethanol was calculated based on elution time and peak areas of known concentration of ethanol. Separations were carried out on a stabilwax ${ }^{\circledR}$ - DA (fused silica, polar phase; crossbond $^{\circledR}$ carbowax $^{\circledR}$ polyethylene glycol) column.

\subsection{Microorganism, medium and yeast cultivation}

The fermenting yeast used in this study was industrial strain Ethanol Red ${ }^{\circledR}$ Saccharomyces cerevisiae. Inoculums were prepared by selecting a single colony from YPD culture plates and inoculating into YPD broth medium. The media consisted of $10 \mathrm{~g} \mathrm{~L}^{-1}$ glucose, $10 \mathrm{~g} \mathrm{~L}^{-1}$ peptone, $5 \mathrm{~g} \mathrm{~L}^{-1}$ yeast extract, $2 \mathrm{~g} \mathrm{~L}^{-1} \mathrm{KH}_{2} \mathrm{PO}_{4}$, and $1 \mathrm{~g} \mathrm{~L}^{-1} \mathrm{MgSO}_{4}$ at $\mathrm{pH} 4.8$. After incubation at $35^{\circ} \mathrm{C}$ for $24 \mathrm{~h}$, the optical density (OD 660) reading of the seed culture reached between 1.5 and 2.0 .

\subsection{Experimental design}

A $3^{3}$ factorial experimental design with a total of 18 experiments was implemented as shown in Table 4 to investigate the responses (maximum ethanol concentration, $E_{\max }$; maximum ethanol yield, $\mathrm{EC}_{\max }$; maximum ethanol volumetric productivity, $\mathrm{Q}_{\mathrm{p} \text { max }}$ and glucose solubility, $\mathrm{Glu}_{\mathrm{s}}$ ) to the three process factors at three levels $\left(\mathrm{S}_{\mathrm{o}}\right.$ at 1.37, 1.92 and 2.37; solid loading at $0.10 \mathrm{~g} \mathrm{~mL}^{-1}$, $0.15 \mathrm{~g} \mathrm{~mL}^{-1}$ and $0.25 \mathrm{~g} \mathrm{~mL}^{-1}$; enzyme loading at 4,10 and $16 \mathrm{FPU}$ $\mathrm{g}^{-1}$ glucan) during SSF of PBT shedding bark. The three levels of $S_{\mathrm{o}}$ $\left(x_{1}\right)$, solid loading $\left(x_{2}\right)$ and enzyme loading $\left(x_{3}\right)$ were represented by $-1,0$ and 1 for low, center and high levels respectively (Table 4). Upon completion of all experiments the regression analysis of experimental data was performed in Minitab 16 software to corre-

\section{[Oligomeric sugar $\left.\left(\mathrm{g} \mathrm{L}^{-1}\right)\right]=\left[\right.$ Total sugars $\left(\mathrm{g} \mathrm{L}^{-1}\right)$ in the hydrolysate corrected for degradation $]$ - [Monomeric sugar $\left(\mathrm{g} \mathrm{L}^{-1}\right)$ in the hydrolysate liquid before autoclaving] \\ The concentrations of 5-hydroxymethylfurfural (HMF) and fur- fural in the prehydrolysates were analyzed by HPLC (Jasco, Japan) equipped with a PU-2089 pump, a degasser, an UV-2077 detector and a Luna C-18 column ( $5 \mu \mathrm{m}$ particle size, $250 \times 4.6 \mathrm{~mm}$, Phe- nomenex, USA). The column temperature was $25^{\circ} \mathrm{C}$, the mobile phase was acetonitrile: water: acetic acid $(11: 88: 1 \mathrm{v} / \mathrm{v} / \mathrm{v})$ at a flow \\ late the experimental data, to determine the coefficients in the model and the significance of the coefficients. The established polynomial equations were used to plot 3-D surfaces and 2-D con- tours in Minitab to visualize individual and interactive effects of the process factors on the response variables within their prede- fined ranges.} rate of $1 \mathrm{~mL} \mathrm{~min}^{-1}$. The injection volume was $20 \mu \mathrm{L}$ and absorption wavelength was $276 \mathrm{~nm}$. The same HPLC for the analysis of phenolic compounds was used with the mobile phase consisted of solvent $A$ (water: acetic acid $=100: 1, v / v$ ) and solvent $B$ (methanol: acetonitrile: acetic acid $=75: 25: 1, \mathrm{v} / \mathrm{v} / \mathrm{v}$ ) at a flow rate of

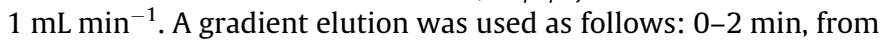
0 to $5 \%$ solvent $B ; 2$ to $10 \mathrm{~min}$, from 5 to $25 \%$ solvent $\mathrm{B} ; 10$ to $20 \mathrm{~min}$, from $25 \%$ to $40 \%$ solvent B; 20 to $30 \mathrm{~min}$, from $40 \%$ to $50 \%$ solvent B; 30 to $40 \mathrm{~min}$, from $50 \%$ to $100 \%$ solvent B; 40 to $45 \mathrm{~min}, 100 \%$ solvent B; 44 to $55 \mathrm{~min}, 100$ to $5 \%$ solvent B. UV detection was performed at $280 \mathrm{~nm}$. Under these conditions it allowed the simultaneous detection of hydroxybenzoic and hydroxycinnamic acids. Phenolic compounds in the samples were identified by comparing their relative retention times and UV spectra with those of authentic standards. In the same way, the concentrations of sugars, furfural and HMF were calculated by using calibration curves obtained from standards. Ethanol content was

\subsection{SSF of SCW treated solids}

SSF was carried out in a $250 \mathrm{~mL}$ Erlenmeyer flask equipped with a bubble trap to maintain anaerobic condition in an orbital shaker $\left(150 \mathrm{rpm}, 37^{\circ} \mathrm{C}\right.$ ) for $120 \mathrm{~h}$. The fermentation flask contained $10 \mathrm{~mL}$ nutrient solution (containing $10 \mathrm{~g} \mathrm{~L}^{-1}$ peptone and $5 \mathrm{~g} \mathrm{~L}^{-1}$ yeast extract), mixed with the desired solid and enzyme loadings, $5 \mathrm{~mL}$ sodium citrate buffer at $\mathrm{pH} 4.8$, and $10 \mathrm{~mL}$ inoculums. The total volume of working slurry was $100 \mathrm{~mL}$. Sample $(1 \mathrm{~mL})$ was withdrawn from SSF medium at preset times $(0,3,6,12,24,48,72$, 96 and $120 \mathrm{~h})$, centrifuged $(16,000 \mathrm{~g})$ and analyzed for ethanol and glucose. The enzyme used in this study was "Celluclast ${ }^{\circledR}$ $1.5 \mathrm{~L}$ " cellulases (from Trichoderma reesei) purchased from Sigma Aldrich Co. (St. Louis, USA). Cellulase activity was determined using the Filter Paper assay. Ethanol yield (\% cellulose conversion) was calculated as: 
$\%$ Cellulose conversion $=\frac{[\text { EtOH }]_{f}-[\text { EtOH }]_{i}}{0.51(f[\text { biomass }] 1.111)} \times 100 \%$

Where

$[\mathrm{EtOH}]_{\mathrm{f}}$ : Ethanol concentration at the end of the fermentation $\left(\mathrm{g} \mathrm{L}^{-1}\right)$

$[\mathrm{EtOH}]_{\mathrm{o}}$ :Ethanol concentration at the beginning of fermentation ( $\mathrm{g} \mathrm{L}^{-1}$ ) which is zero

[Biomass]: Dry biomass concentration at the beginning of fermentation $\left(\mathrm{g} \mathrm{L}^{-1}\right) f$ : Cellulose fraction of dry biomass $\left(\mathrm{g} \mathrm{g}^{-1}\right)$

0.51: Conversion factor for glucose to ethanol based on stoichiometric biochemistry of yeast

1.111: Converts cellulose to equivalent glucose

\section{Results and discussion}

\subsection{SCW pretreatment of PBT shedding bark}

In biorefinery based on lignocellulosic materials, which has sugars as intermediates, it is necessary to break down the feedstock's structure and obtain sugars from cellulose and hemicellulose. Hence pretreatment is needed to prepare the feedstock in order to improve conversion of sugars (Carolina et al., 2011). Moreover, in order to obtain high ethanol concentration in fermentation, a high cellulose concentration in the medium is required. Removal of non-cellulose components by pretreatment is beneficial to increasing in cellulose content. HCW mainly solubilize hemicellulose under controlled $\mathrm{pH}$; hence it allows better accessibility of cellulose and to avoid the formation of inhibitors (Hendriks and Zeeman, 2009). The ionic product of HCW at subcritical condition is up to three orders of magnitude higher than that at ambient conditions, which means that using subcritical water (SCW) is capable of achieving the same results as employing either acidic or alkaline catalysts (Alenezi et al., 2009). The hydrolysis of Japanese beech (Fagus crenata) by batch and semi-flow SCW at $170-290{ }^{\circ} \mathrm{C}$ demonstrated an increased production of total saccharides with temperature for both batch and semi-flow hot-compressed water treatments (Lu and Saka, 2010). The PBT shedding bark was pretreated with SCW at mild temperature $\left(120-180^{\circ} \mathrm{C}\right)$ for the purpose of extracting xylan and obtaining high glucan concentration in the biomass to apply for simultaneous saccharification and fermentation. Table 1 shows the lists of the range of temperature and residence time and the calculated severity $\left(S_{0}\right)$ of each pretreatment. The value of $S_{0}$ ranges from 0.46 to 2.59 . The yield of xylose increased with severity till it reach the peak at a $S_{0}$ of 2.37 (Fig. 1A). However, further increase of severity $\left(S_{0}>2.37\right)$ resulted in a decrease of xylose yield, presumably due to degradation. At a $S_{\mathrm{o}}$ of 2.25 , where xylose yield is close to its peak value, significant glucan depolymerization was evident. Glucose release kept increasing with increasing $\mathrm{S}_{\mathrm{o}}$. A notable difference between solubilization of the xylan and glucan fractions was the fact that the latter did not reach its potential maximum under the study conditions (Fig. 1A), hence SCW pretreatment of PBT primarily affords xylan extraction and as a result the solid residue became rich in glucan. In pretreatment, it has been shown that cellulose degradation was more difficult than hemicellulose under the same conditions due to their different structures, but the trends of hemicellulose and cellulose were similar (Carolina et al., 2011).
A
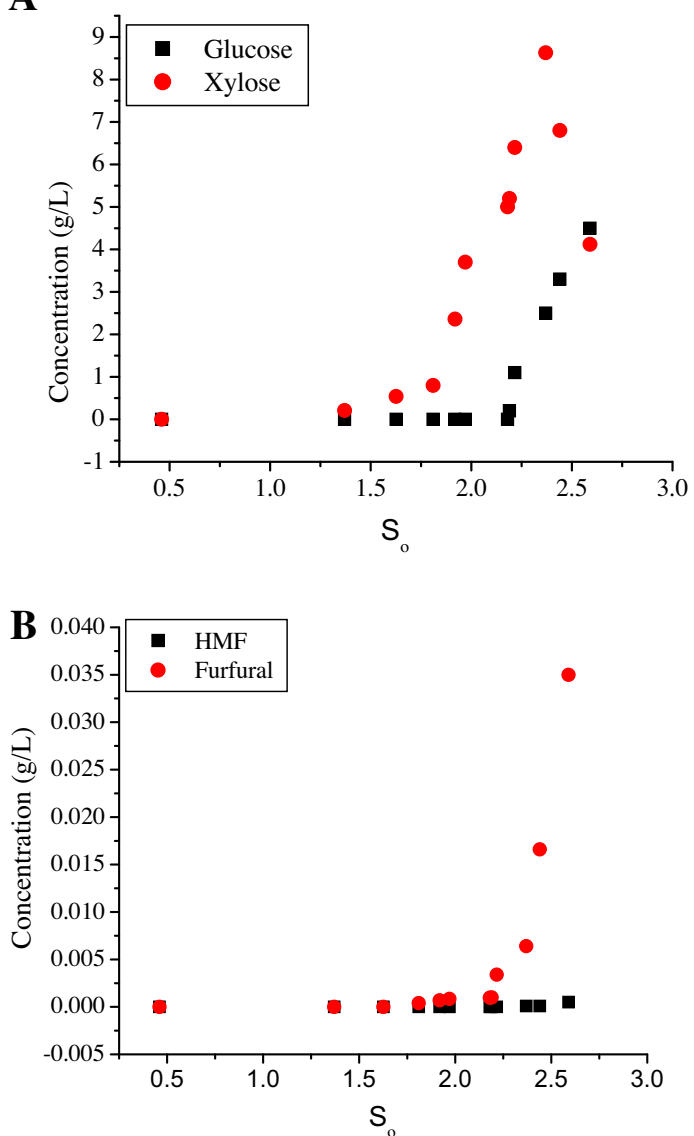

Fig. 1. Compositions of sugars (A) and inhibitors (B) as function of severity, $\mathrm{S}_{\mathrm{o}}$, in PBT shedding bark prehydrolysate after SCW water pretreatment.

During pretreatments, various inhibitors may be formed, such as phenolics, furfural and HMF. These inhibitors originate from the release and subsequent degradation of carbohydrate and lignin. Formation of these compounds is directly proportional to pretreatment severity (Hendriks and Zeeman, 2009). In Fig. 1B, the formation of furfural and HMF, the two major degradation products of pentose and hexose sugars, is presented. Pretreatment conditions which increased low level accumulation of furfural (Fig. 1B) strongly correlated to conditions associated with the progression of xylose loss (Fig. 1A). In contrast, the appearance of low level of HMF does not appear to correlate to glucose loss during pretreatment but presumably resulted from the degradation of minor hexose sugars associated with the hemicelluloses fraction. In general the milder temperature $\left(120-180^{\circ} \mathrm{C}\right)$ of SCW pretreatment used in this study requires relatively lower energy consumption and prevents extensive xylose and glucose degradation. In addition, since no chemicals is required making SCW pretreatment an environmentally benign and economical approach. Based on the pretreatment findings, three $S_{\mathrm{o}}$ values $(1.81,1.92$ and 2.37), which can extract hemicellulose with very low accumulation of inhibitors and high glucan recovery, were selected for the subsequent study in this work.

Table 1

SCW pretreatment conditions and the corresponding severity value for PBT shedding bark.

\begin{tabular}{|c|c|c|c|c|c|c|c|c|c|c|c|c|}
\hline Pretreatment No. & 1 & 2 & 3 & 4 & 5 & 6 & 7 & 8 & 9 & 10 & 11 & 12 \\
\hline Temperature $\left({ }^{\circ} \mathrm{C}\right)$ & 120 & 120 & 120 & 140 & 140 & 140 & 160 & 160 & 160 & 180 & 180 & 180 \\
\hline Time (min) & 15 & 30 & 60 & 15 & 30 & 60 & 15 & 30 & 60 & 15 & 30 & 60 \\
\hline Severity, $S_{o}$ & 0.46 & 1.37 & 1.81 & 1.63 & 1.92 & 2.23 & 1.97 & 2.19 & 2.44 & 2.18 & 2.37 & 2.59 \\
\hline
\end{tabular}


Table 2

Compositions of SCW prehydrolysate and solid residue from PBT shedding bark (0.1 $\mathrm{g} \mathrm{mL}^{-1}$ solid load).

\begin{tabular}{llll}
\hline Composition of Prehydrolysate $\left(\mathrm{g} \mathrm{L}^{-1}\right)$ & $\mathrm{S}_{\mathrm{o}} 1.81$ & $\mathrm{~S}_{\mathrm{o}} 1.92$ & $\mathrm{~S}_{\mathrm{o}} 2.37$ \\
\hline Xylose & 0.24 & 3.37 & 8.63 \\
Glucose & $\mathrm{ND}$ & $\mathrm{ND}$ & 4.5 \\
Galactose & $\mathrm{ND}$ & 0.12 & 0.44 \\
Olig-xylose & 0.92 & 4.5 & 4.2 \\
Olig-glucose & $\mathrm{ND}$ & 0.42 & 1.1 \\
Furfural & $\mathrm{ND}$ & 0.0001 & 0.0064 \\
HMF & $\mathrm{ND}$ & $\mathrm{ND}$ & 0.001 \\
3,4 Dihydro cinnamic acid & $\mathrm{ND}$ & 0.0034 & 0.01 \\
p-coumaric acid & $\mathrm{ND}$ & 0.0012 & 0.008 \\
Ferulic acid & $\mathrm{ND}$ & 0.00012 & 0.008 \\
Composition of solid Residue (wt.\%) & & & \\
Xylan & 15 & 9.17 & 5.4 \\
Glucan & 48.2 & 51 & 58 \\
Lignin $^{\mathrm{a}}$ & 19 & 18.1 & 16.2 \\
\hline
\end{tabular}

a Acid soluble lignin (ASL) plus acid insoluble lignin (AIL).

b Not detected.

\subsection{Composition of PBT and mass balance}

The compositions of PBT shedding bark hydrolysis liquor (prehydrolysate) and solid residue are listed in Table 2. At low $S_{0}$ (1.81), little xylose (1.08\% of xylan) was recovered in the prehydrolysates. This does not imply poor solublization of hemicelluloses; rather the polymer was solubilized primarily in oligomeric forms (5\% of xylan). Previous studies on hydrolysis of lignocelluloses biomass using HCW indicated that the solubilized hemicelluloses appeared mainly in oligomeric form at lower severities (Garrote et al., 1999; Lu and Saka, 2010). As $S_{0}$ increased the yield of xylose also increased. A maximum of $47 \%$ of available xylan was solubilized into monomeric xylose and a total $72 \%$ of xylan in oligomeric and monomeric forms at $S_{0}=2.37$ (Table 2). Hence the yield of xylose was favored at a $\mathrm{S}_{\mathrm{o}}$ of 2.37, which indicates that oligomeric xylose changed into monomeric forms. At the same $S_{o}$ (2.37) significant concentration of glucose and galactose were analyzed in prehydrolysate which may resulted from dissolution of the minor hexose sugars associated with the hemicelluloses and amorphous cellulose. Moreover trace amounts phenolic compounds were identified in the prehydrolysates at $\mathrm{S}_{\mathrm{o}}$ of 1.92 and 2.37. At $\mathrm{S}_{\mathrm{o}}=2.37$, eight phenolic compounds were identified: gallic, caffeic, 3,4dihydroxycinamic, syringic, ferulic, p-coumaric, p-hydroxybenzoic, and vanillic acids at trace amounts. However only 3,4dihydroxycinamic, p-coumaric and vanillic acids were quantified (Table 2) which showed higher yields than the other phenols. It has been reported that phenolic compounds exist in insoluble bound forms with lignin and carbohydrates (hemicellulose and cellulose) in lignocellulosic biomass cell wall (Hendriks and Zeeman, 2009); hence, the existing bonds (ester and/or ether bonds) between these materials can be hydrolyzed by SCW. However further studies are needed to obtain maximum recovery of phenolics from PBT shedding bark. The extraction of xylan and acid soluble lignin enriched glucan content in the residue solid (Table 2).

Under subcritical condition water can act as acid/base catalyst and can be employed in mild hydrolysis reaction (Alenezi et al., 2009), hence this property is believed to favor xylan and lignin solubilization. The major portion of acid insoluble lignin was recovered in the pretreated solids while the acid soluble lignin solublized in the SCW prehydrolysate as shown in the mass balance (Table 3). Thus a weight loss of the residue solid after SCW pretreatment was mainly attributed to xylan and acid soluble lignin dissolution into prehydrolysate as monomeric/ oligomeric xylose, furfural, solubilized lignin and phenolics. In general, the analysis of carbohydrate and non carbohydrate composition of PBT shedding bark showed good mass balance. The calculation incorporates the assumptions of including total extractives into prehydrolysate and the balance of ash. The total mass balance was $99.6 \%$ to $95 \%$ for native and pretreated biomass from HPLC analysis (Table 3 ). It is obvious that xylan present in the prehydrolysate is mainly in monomeric and oligomeric xylose forms and furfural. For total lignin mass balance the phenolic compounds released and solubilized and recovered lignins were considered. A small difference in mass balance between the native and pretreated samples confirms the presence of other unknown compounds from the decomposition of PBT in SCW medium which could not be identified in this study.

\subsection{Effects of SSF parameters on glucan dissolution and ethanol production}

Minimizing cellulase dosage is important for cost reduction of cellulosic ethanol production. It is also important to identify the optimum solid loading. At high solid loading the glucose solubility $\left(\mathrm{Glu}_{\mathrm{s}}\right)$ was delimited by the low enzyme dosage (4.0 FPU g ${ }^{-1}$ ) as shown in Table 4, Exp. No 1-3; and Exp. No 7-9. The Glu results clearly indicate that hydrolysis was greatly improved by using high enzyme dosage which positively affected maximum ethanol production $\left(\mathrm{E}_{\max }\right)$ and ethanol yield $\left(\mathrm{EC}_{\max }\right)$. Similarly high solid loading had a positive effect on $\mathrm{Glu}_{\mathrm{s}}$ and $\mathrm{E}_{\max }$. However, it had opposite effect on $\mathrm{EC}_{\max }$ (Table 4).

Saccharification of SCW pretreated biomass allowed high glucan dissolution (up to 83\%) and significant differences in $\mathrm{Glu}_{\mathrm{s}}$ were observed between the pretreatment severities (1.81, 1.92 and

Table 3

Mass balance ${ }^{\mathrm{a}}$ in native and SCW pretreated PBT.

\begin{tabular}{|c|c|c|c|c|c|c|c|}
\hline & \multirow[t]{2}{*}{ Native } & \multicolumn{2}{|l|}{$\underline{S_{o}}=1.81$} & \multicolumn{2}{|l|}{$S_{o}=1.92$} & \multicolumn{2}{|l|}{$\mathrm{S}_{\mathrm{o}}=2.37$} \\
\hline & & Solid residue & Extraction liquor & Solid residue & Extraction liquor & Solid residue & Extraction liquor \\
\hline \multicolumn{8}{|l|}{ Carbohydrates $^{\mathrm{b}}$} \\
\hline Glucan & 49.7 & 49.15 & - & 47.6 & 1.16 & 41.2 & 5.75 \\
\hline Xylan & 18.4 & 16.1 & 1.16 & 9.7 & 8.14 & 5.7 & 13.2 \\
\hline Galactan & 0.42 & - & 0.32 & - & 0.4 & - & 0.32 \\
\hline \multicolumn{8}{|l|}{ Non-carbohydrates } \\
\hline Acid insoluble lignin & 18.6 & 18.6 & - & 17.5 & - & 16.7 & - \\
\hline Acid soluble lignin & 1.2 & 1.13 & 0.11 & 0.63 & 0.74 & - & 1.16 \\
\hline Ash & 1.62 & 1.6 & - & 1.4 & - & 1.16 & - \\
\hline \multirow[t]{2}{*}{ Extractives } & 9.7 & - & 9.7 & - & 9.7 & - & 9.7 \\
\hline & & 86.6 & 11.29 & 76.8 & 20.14 & 64.8 & 30.13 \\
\hline Overall mass balance & 99.6 & 97.9 & & 96.94 & & 94.9 & \\
\hline
\end{tabular}

\footnotetext{
a Composition of dry native PBT (wt.\%).
}

b Total carbohydrate in non solubilized form or solubilized monomeric, oligomeric and/or degraded products (furfural and HMF). 
2.37). For instance in Table 4 Exp. No 4 affords a $\mathrm{Glu}_{\mathrm{s}}$ of $25.5 \mathrm{~g} \mathrm{~L}^{-1}$ (53\% of glucan), and Exp. No 10 and Exp. No 13 give a Glu $\mathrm{s}_{\mathrm{s}}$ of $28.5 \mathrm{~g}$ $\mathrm{L}^{-1}$ (58\% of glucan) and $35.2 \mathrm{~g} \mathrm{~L}^{-1}$ (64\% of glucan) respectively. In the same way, Exp No 5, Exp. No 11 and Exp. No 14 give a Glu of $38.4 \mathrm{~g} \mathrm{~L}^{-1}$ (53\% of glucan), $48.8 \mathrm{~g} \mathrm{~L}^{-1}$ (66.4\% of glucan) and $58.9 \mathrm{~g} \mathrm{~L}^{-1}$ (71.4\% of glucan), respectively. Proximity in $\mathrm{Glu}_{\mathrm{s}}$ between the $\mathrm{S}_{\mathrm{o}}$ (1.92 and 2.37) was observed when higher solid loadings was implemented. For instance at $0.25 \mathrm{~g} \mathrm{~mL}^{-1}$ solid loading (Exp. No 6 and 9, Table 4) close glucan dissolution (54.7\% and $56.9 \%$, respectively) was observed. However, closeness in $\mathrm{Glu}_{\mathrm{s}}$ did not assure comparable $\mathrm{E}_{\max }$ in different experiments. This event was a result of mass transfer limitations at high solid loadings and $S_{0}$. As shown in Table 3, there is a clear difference in xylan and lignin recovery between the $\mathrm{S}_{\mathrm{o}}(1.92$ and 2.37$)$ that resulted in the solubility and the viscosity difference among the slurries. On the other hand $\mathrm{Glu}_{\mathrm{s}}$ from biomass at low $\mathrm{S}_{\mathrm{o}}(1.81)$ was greatly reduced with increasing solid loading. For instance at $0.15 \mathrm{~g} \mathrm{~mL}^{-1}$ solid loading (Exp No 5), 53\% of glucan solubilization was obtained. However at $0.25 \mathrm{~g} \mathrm{~mL}^{-1}$ solid loading (Exp No 6) only $37 \%$ of glucan solubility can be achieved. Consequently, $\mathrm{S}_{\mathrm{o}}$ affected the efficiency of enzyme and yeast. In this work SSF preformed with substrates treated at $S_{o}=2.37$ led to good ethanol production and yield.

The experimental data given in Table 4 were used to develop a full quadratic polynomial regression model (Eqn. 4) to predict the dependent variables y $\left(\mathrm{Glu}_{\mathrm{s}} \mathrm{E}_{\max }, \mathrm{EC}_{\max }\right.$ and $\mathrm{Q}_{\mathrm{p} \text { max }}$ ) as a function of the three process parameters: $\mathrm{x}_{1}\left(\mathrm{~S}_{0},{ }^{\circ} \mathrm{C}\right), \mathrm{x}_{2}$ ( solid loading, $\mathrm{g} \mathrm{mL}^{-1}$ ) and $x_{3}$ (enzyme loading, FPU $g^{-1}$ glucan). In Eqn.4, $b_{o}$ is the offset coefficient, $b_{i}$ is the linear coefficient, $b_{i i}$ is the quadratic coefficient and $b_{i j}$ is the interaction coefficient. The coefficients and the corresponding p-values of the models are listed in Table 5. The fitted models ANOVA results (Table S1 in Supplementary material-1) showed that the $\mathrm{R}^{2}$ values were at least 0.97 , which indicate the aptness of the models to explain responses.

$Y=b o+\sum_{1}^{i} b x_{i}+\sum_{1}^{i} b_{i} x_{i}^{2}+\sum_{1}^{i} \sum_{2}^{j} b_{i j} x_{i j}$

Analysis of the p-values of each term in the models was used to determine the significance levels of the three process parameters and their interactions on responses. As shown in Table 5, linear interactions of independent variables had high significant effect $(\mathrm{p}<0.001)$. Moreover the combined effects of all independent variables significantly contributed to dependent variables. However the square interaction of $S_{o}\left(b_{11}\right)$ on all dependent variables is not significant, this interaction could be removed from the equations without significant effect on the accuracy of the predicted dependent variables. The equations were used to plot response surfaces and their corresponding contours to show $\mathrm{Glu}_{\mathrm{s}}$, $\mathrm{E}_{\max }$, $\mathrm{EC}_{\text {max }}$ and $\mathrm{Q}_{\mathrm{p} \text { max }}$ by different levels of the process variables with one variable fixed at center level (Supplementary material-2). Figs. S1-A and B show that there are significant interactions of $S_{o}$ with the other process parameters on $\mathrm{Glu}_{\mathrm{s}}$. Similar interactions were ob-

Table 4

Operational parameters and results in experimental design carried out to optimize the SSF of SCW treated PBT shedding bark.

\begin{tabular}{|c|c|c|c|c|c|c|c|c|c|c|}
\hline \multirow[t]{2}{*}{ Exp. No } & \multicolumn{3}{|c|}{ Independent variables $^{\mathrm{a}}$} & \multirow[t]{2}{*}{$\mathrm{x}_{1}$} & \multirow[t]{2}{*}{$\mathrm{x}_{2}$} & \multirow[t]{2}{*}{$\mathrm{x}_{3}$} & \multicolumn{4}{|c|}{ Dependent variables $^{\mathrm{b}}$} \\
\hline & $\mathrm{S}_{0}$ & EL (FPU) & $\mathrm{SL}\left(\mathrm{g} \mathrm{mL}^{-1}\right)$ & & & & $\mathrm{Glu}_{\mathrm{s}}(\mathrm{g} / \mathrm{L})$ & $\mathrm{E}_{\max }(\mathrm{g} / \mathrm{L})$ & $\mathrm{EC}_{\max }(\mathrm{g} / 100 \mathrm{~g})$ & $\mathrm{Q}_{\mathrm{p} \max }(\mathrm{g} / \mathrm{L} / \mathrm{h})$ \\
\hline 1 & 1.81 & 4 & 0.10 & -1 & -1 & -1 & 16.7 & 4.5 & 16.5 & 0.094 \\
\hline 2 & 1.81 & 4 & 0.15 & -1 & -1 & 0 & 24.3 & 6.6 & 16.1 & 0.14 \\
\hline 3 & 1.81 & 4 & 0.25 & -1 & -1 & 1 & 32.9 & 9.6 & 14.07 & 0.20 \\
\hline 4 & 1.81 & 10 & 0.10 & -1 & 0 & -1 & 25.5 & 8.5 & 31.15 & 0.18 \\
\hline 5 & 1.81 & 10 & 0.15 & -1 & 0 & 0 & 38.4 & 11.3 & 27.6 & 0.24 \\
\hline 6 & 1.81 & 10 & 0.25 & -1 & 0 & 1 & 44.7 & 13.5 & 19.8 & 0.28 \\
\hline 7 & 1.97 & 4 & 0.10 & 0 & -1 & -1 & 22.8 & 6.9 & 25.04 & 0.145 \\
\hline 8 & 1.97 & 4 & 0.15 & 0 & -1 & 0 & 33.7 & 9.5 & 22.8 & 0.19 \\
\hline 9 & 1.97 & 4 & 0.25 & 0 & -1 & 1 & 42 & 12.8 & 18.44 & 0.27 \\
\hline 10 & 1.97 & 10 & 0.10 & 0 & 0 & -1 & 28.5 & 17.7 & 63.76 & 0.37 \\
\hline 11 & 1.97 & 10 & 0.15 & 0 & 0 & 0 & 48.8 & 23.5 & 56.3 & 0.33 \\
\hline 12 & 1.97 & 10 & 0.25 & 0 & 0 & 1 & 67 & 32.2 & 46.32 & 0.45 \\
\hline 13 & 2.37 & 10 & 0.10 & 1 & 0 & -1 & 35.2 & 25 & 80.02 & 0.35 \\
\hline 14 & 2.37 & 10 & 0.15 & 1 & 0 & 0 & 58.9 & 35.8 & 76.36 & 0.5 \\
\hline 15 & 2.37 & 10 & 0.25 & 1 & 0 & 1 & 78.32 & 54.6 & 69.9 & 0.76 \\
\hline 16 & 2.37 & 16 & 0.10 & 1 & 1 & -1 & 44.3 & 29.4 & 93.11 & 0.41 \\
\hline 17 & 2.37 & 16 & 0.15 & 1 & 1 & 0 & 68.5 & 43.7 & 91.25 & 0.61 \\
\hline 18 & 2.37 & 16 & 0.25 & 1 & 1 & 1 & 103.3 & 62.3 & 80.92 & 0.88 \\
\hline
\end{tabular}

${ }^{a} \mathrm{~S}_{\mathrm{o}}$ : severity, SL: solid loading $\left(\mathrm{g} \mathrm{mL}^{-1}\right)$, EL: enzyme loading (FPU/g glucan).

b $\mathrm{Glu}_{\mathrm{s}}$ : solublized glucose concentration $(\mathrm{g} / \mathrm{L}), \mathrm{E}_{\mathrm{MAX}}$ : maximum ethanol concentration $(\mathrm{g} / \mathrm{L})$, $\mathrm{Q}_{\mathrm{PMAX}}$ : volumetric productivity at $\mathrm{E}_{\mathrm{MAX}}(\mathrm{g} / \mathrm{L})$, $\mathrm{EC}_{\mathrm{MAX}}$ : maximum ethanol conversion ( $\mathrm{g}$ ethanol/100 $\mathrm{g}$ potential ethanol).

Table 5

Regression coefficients and statistical parameters measuring the correlation and significance of the models.

\begin{tabular}{|c|c|c|c|c|c|c|c|c|}
\hline & \multicolumn{2}{|l|}{$\mathrm{Glu}_{\mathrm{s}}$} & \multicolumn{2}{|l|}{$\mathrm{E}_{\max }$} & \multicolumn{2}{|l|}{$\mathrm{EC}_{\max }$} & \multicolumn{2}{|l|}{$\mathrm{Q}_{\mathrm{p} \max }$} \\
\hline & Coefficient & p-value & Coefficient & p-value & Coefficient & p-value & Coefficient & p-value \\
\hline$b_{o}$ & 52.3851 & 0.000 & 23.4710 & 0.000 & 50.0404 & 0.000 & 0.367131 & 0.000 \\
\hline$b_{1}$ & 11.2380 & 0.000 & 14.1870 & 0.000 & 24.6108 & 0.000 & 0.159475 & 0.000 \\
\hline$b_{2}$ & 13.7366 & 0.000 & 5.820 & 0.004 & 11.5537 & 0.000 & 0.096166 & 0.016 \\
\hline$b_{3}$ & 16.9957 & 0.000 & 8.028 & 0.000 & -5.3937 & 0.000 & 0.110698 & 0.000 \\
\hline$b_{11}$ & 0.8583 & 0.698 & 3.181 & 0.120 & 0.2806 & 0.864 & 0.032222 & 0.449 \\
\hline$b_{22}$ & -1.6183 & 0.522 & -7.544 & 0.007 & -17.7633 & 0.000 & -0.074167 & 0.144 \\
\hline$b_{33}$ & -6.4919 & 0.004 & -1.388 & 0.355 & -0.1638 & 0.897 & -0.004813 & 0.881 \\
\hline$b_{12}$ & 3.1667 & 0.286 & 8.778 & 0.006 & 18.95 & 0.000 & 0.079167 & 0.170 \\
\hline$b_{13}$ & 4.9623 & 0.003 & 4.532 & 0.002 & -0.098 & 0.915 & 0.058275 & 0.032 \\
\hline$b_{23}$ & 6.4943 & 0.002 & 3.481 & 0.021 & -2.3364 & 0.059 & 0.040496 & 0.172 \\
\hline
\end{tabular}


served on $\mathrm{E}_{\max }$ (Fig. S2), $\mathrm{EC}_{\max }$ (Fig. S3) and $\mathrm{Q}_{\mathrm{p} \max }$ (Fig. S4). High ethanol concentration was affected by the three process parameters. It can be seen from Fig. S2-A that at $0.15 \mathrm{~g} \mathrm{~mL}^{-1}$ solid loading, $\mathrm{S}_{\mathrm{o}} \geqslant 2.3$ and enzyme loading $>12.5 \mathrm{FPU} / \mathrm{g}$ glucan should be used to achieve high ethanol concentration. Fig. S2-C shows that at high PBT solid loading, high enzyme loading was required to catalyze the hydrolysis and to achieve high ethanol concentration. In general from Fig. S2-A and B that ethanol concentration higher than $40 \mathrm{~g} \mathrm{~L}^{-1}$ (economical threshold limit) can be achieved at $\mathrm{S}_{\mathrm{o}} \geqslant 2.3$, enzyme loading $\geqslant 15$ FPU $\mathrm{g}^{-1}$ glucan, and solid loading $\geqslant$ $0.15 \mathrm{~g} \mathrm{~mL}^{-1}$. The interaction between solid loading and $\mathrm{EC}_{\max }$ shows that solid loading had a decreasing effect on $\mathrm{EC}_{\max }$ (Figs. S3-A and B), as a result of mass transfer limitation. Moreover considering the regression coefficients of $\mathrm{EC}_{\max }$ (Table 5), it can be seen the square interaction of solid loading $\left(\mathrm{b}_{22}\right)$ had a negative values and had high significant effects $(\mathrm{p}<0.001)$ on $\mathrm{EC}_{\max }$.

\subsection{Time courses of SSF}

All SSFs were performed using the washed solid fraction to remove sugars solubilized during pretreatment and potential inhibitors (Fig. 1) that could affect enzymatic hydrolysis and fermentation. In an attempt to obtain ethanol concentration exceeding the economical threshold limit $(4-5 \%, v / v)$, the experiments were carried out with a substrate loading of 0.15 and $0.25 \mathrm{~g} \mathrm{~mL}^{-1}$. Additionally, experiment with $0.10 \mathrm{~g} \mathrm{~mL}^{-1}$ was performed in order to study the effect of substrate loading on ethanol production by $S$. cerevisiae.

Fig. 2 shows the time courses of ethanol and glucose concentrations in SSF with $0.10 \mathrm{~g} \mathrm{~mL}^{-1}, 0.15 \mathrm{~g} \mathrm{~mL}^{-1}$ and $0.25 \mathrm{~g} \mathrm{~mL}^{-1}$ solid loadings. In general, glucose concentration increased sharply in the first $24 \mathrm{~h}$ of SSF depending on the solid and enzyme loadings. However, the concentration decreased as the SSF progressed which was accompanied by a rapid increase of fermentation product. In the first $12 \mathrm{~h}$, the differences in ethanol concentrations were insignificant in all cases since yeast cells were adapting to the new environment. The delay or lag phase was more obvious and extended up to $24 \mathrm{~h}$ when substrate loading was 0.15 or $0.25 \mathrm{~g} \mathrm{~mL}^{-1}$. The lag phase due to the adaptation of yeast to fermentation conditions and its duration is related to solids loading (Hoyer et al., 2009). A longer lag phase in SSF performed at high solid loading of other lignocellulosic materials using inoculums of $S$. cerevisiae has been reported (Sassner et al., 2006). In most experiments of this work, the highest ethanol concentrations were obtained at $72 \mathrm{~h}$ and at high solid loadings $\left(0.25 \mathrm{~g} \mathrm{~mL}^{-1}\right.$ and $\left.0.15 \mathrm{~g} \mathrm{~mL}^{-1}\right)$. Maximum concentration (63.2 $\mathrm{g} \mathrm{L}^{-1}$ ) was obtained under the following conditions: pretreatment at $S_{\mathrm{o}}=2.37$, SSF for $72 \mathrm{~h}, 0.25 \mathrm{~g} \mathrm{~mL}^{-1}$ solid loading and $16 \mathrm{FPU} \mathrm{g}^{-1}$ glucan enzyme loading. The volumetric productivity $\left(Q_{p}\right)$ in the first $24 \mathrm{~h}$ of SSF was higher for $0.10 \mathrm{~g} \mathrm{~mL}^{-1}$ solid loading (data not shown), owing to favorable kinetics of cellulose hydrolysis in the early stage. At higher solid loadings $\left(0.15 \mathrm{~g} \mathrm{~mL}^{-1}\right.$ and $0.25 \mathrm{~g} \mathrm{~mL}^{-1}$ ), after $24 \mathrm{~h}$ of SSF the slurry become less viscous hence the mass transfer limitation was reduced and $Q_{p}$ increased. The volumetric productivity at the highest ethanol concentration $\left(Q_{p}\right.$ max) was analyzed (Table 4 ) since $Q_{p}$ at random time lacks practical interest (Romaní et al., 2012). The variation range determined for $\mathrm{Q}_{\mathrm{pmax}}$ was $0.094-0.88 \mathrm{~g}\left(\mathrm{~L}^{-1} \mathrm{~h}^{-1}\right)$, and it was affected by all process parameters. All SSF carried out using $\mathrm{S}_{\mathrm{o}} 1.81$ and some of SSF implementing $S_{\mathrm{o}} 1.91$ (Exp. No 7-10, Table 4) attained $E_{\max }$ in $48 \mathrm{~h}$ with $\mathrm{EC}_{\max }$ values from $14.07 \%$ to $63.8 \%$, while the rest (Exp. No 11-18, Table 4) attained maxima after $72 \mathrm{~h}$ of SSF, and the $\mathrm{EC}_{\max }$ varied from $56.3 \%$ to $93.1 \%$. Longer fermentation times resulted in higher conversion.

For comparison, Table 6 lists experimental results obtained in this work and data reported in related studies. At higher solid loadings ( 0.15 and $0.25 \mathrm{~g} \mathrm{~mL}^{-1}$ ), the SSF reaction matrix became
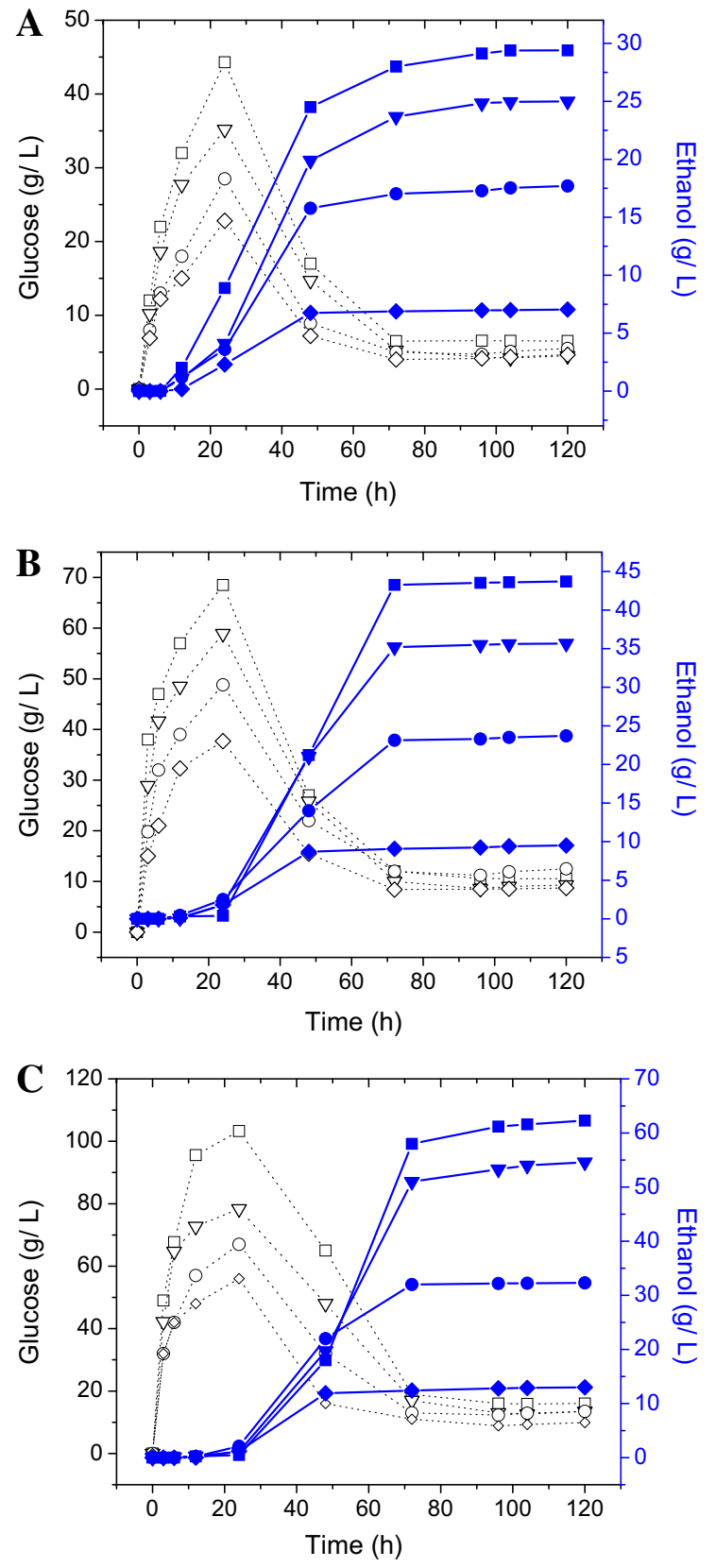

Fig. 2. Time courses of ethanol $\left(S_{0} 2.37,16\right.$ FPU: $(\boldsymbol{\nabla}) ; S_{0} 2.37,10$ FPU: $(\boldsymbol{\nabla}) ; S_{0} 1.97$, $10 \mathrm{FPU}(\bullet) ; \mathrm{S}_{\mathrm{o}}$ 1.97, 4 FPU: $\left.(\diamond)\right)$ and glucose $\left(\mathrm{S}_{\mathrm{o}}\right.$ 2.37, 16 FPU: $(\square) ; \mathrm{S}_{\mathrm{o}} 2.37,10 \mathrm{FPU}:$ $(\nabla) ; \mathrm{S}_{\mathrm{o}}$ 1.97, 10 FPU: $\left.(\bigcirc) ; \mathrm{S}_{\mathrm{o}} 1.97,4 \mathrm{FPU}:(\diamond)\right)$ concentration in SSF experiments at solid loadings: $0.10 \mathrm{~g} \mathrm{~mL}^{-1}(\mathrm{~A}) ; 0.15 \mathrm{~g} \mathrm{~mL}^{-1}(\mathrm{~B}) ; 0.25 \mathrm{~g} \mathrm{~mL}^{-1}(\mathrm{C})$.

highly viscous with unequal distribution of slurry resulting in ethanol yield less than the theoretical value. Pessani et al. (2011) reported that switchgrass treated with hydrothermolysis at $200^{\circ} \mathrm{C}$ gave $22.5 \mathrm{~g} \mathrm{~L}^{-1}$ ethanol concentration and $86 \%$ ethanol yield at $0.08 \mathrm{~g} \mathrm{~mL}^{-1}$ solid loading, while at $0.12 \mathrm{~g} \mathrm{~mL}^{-1}$ solid loading ethanol concentration increased to $32 \mathrm{~g} \mathrm{~L}^{-1}$ but ethanol yield decreased to $82 \%$. Steam exploded $\left(205^{\circ} \mathrm{C}\right)$ and washed corn stover at high enzyme loading ( $20 \mathrm{FPU} \mathrm{g}^{-1}$ ) produced an ethanol concentration of $41 \mathrm{~g} \mathrm{~L}^{-1}$ and $49 \mathrm{~g} \mathrm{~L}^{-1}$ at $0.25 \mathrm{~g} \mathrm{~mL}^{-1}$ and $0.30 \mathrm{~g} \mathrm{~mL}^{-1}$ solid loadings, respectively with high yield (92-94\%) (Lu et al., 2010). However, using similar pretreatment and biomass loading $(0.25$ and $0.30 \mathrm{~g} \mathrm{~mL}^{-1}$ ), low ethanol yield (64.8\% and $52.1 \%$ ) and ethanol production ( $39.3 \mathrm{~g} \mathrm{~L}^{-1}$ and $40.6 \mathrm{~g} \mathrm{~L}^{-1}$ ) were reported by Zhang et al. (2010) when an enzyme activity of $13.6 \mathrm{FPU} \mathrm{g}^{-1}$ was used. Using 
Table 6

Experimental data obtained in this work and results reported in related studies.

\begin{tabular}{|c|c|c|c|c|c|c|}
\hline Raw Material & Pretreatment condition & $\begin{array}{l}\mathrm{SL}^{\mathrm{a}}(\mathrm{g} \\
\left.\mathrm{mL}^{-1}\right)\end{array}$ & $\begin{array}{l}\mathrm{EL}^{\mathrm{b}} \\
(\mathrm{FPU} / \mathrm{g})\end{array}$ & $\begin{array}{l}E_{\max }{ }^{c} \\
(g / L)\end{array}$ & $\begin{array}{l}\mathrm{EC}_{\max }{ }^{\mathrm{d}} \\
(\%)\end{array}$ & Reference \\
\hline Switchgrass & Hydrothermolysis at $200^{\circ} \mathrm{C}$ for $10 \mathrm{~min}$ & 0.08 & $58^{\mathrm{e}}$ & 22.5 & 86 & Pessani et al., 2011 \\
\hline Switchgrass & Hydrothermolysis at $200^{\circ} \mathrm{C}, 10 \mathrm{~min}$ & 0.12 & $58^{\mathrm{e}}$ & 32 & 82 & Pessani et al., 2011 \\
\hline Corn stover & Steam explosion at $200^{\circ} \mathrm{C}$ for $4 \mathrm{~min}$ & 0.30 & $13.6^{\mathrm{f}}$ & 40.6 & 52.1 & Zhang et al. (2010) \\
\hline Corn stover & Steam explosion at $200^{\circ} \mathrm{C}$ for $4 \mathrm{~min}$ & 0.25 & 13.6 & 39.3 & 64.8 & Zhang et al. (2010) \\
\hline Corn stover & Steam explosion at $205^{\circ} \mathrm{C}$ for $6 \mathrm{~min}$ & 0.25 & 20 & 41 & 92 & Lu et al., 2010 \\
\hline Corn stover & Steam explosion at $205^{\circ} \mathrm{C}$ for $6 \mathrm{~min}$ & 0.30 & 20 & 49.5 & 94 & Lu et al., 2010 \\
\hline Barley straw & Steam explosion at $210^{\circ} \mathrm{C}$ for $5 \mathrm{~min}$ & 0.15 & $-\mathrm{g}$ & 26 & - & $\begin{array}{l}\text { García-Aparicio } \\
\text { et al., } 2011\end{array}$ \\
\hline Barley straw & Steam explosion at $210^{\circ} \mathrm{C}$ for $5 \mathrm{~min}$ & 0.10 & - & 19.4 & - & $\begin{array}{l}\text { García-Aparicio } \\
\text { et al., } 2011\end{array}$ \\
\hline Corn cobs & $\begin{array}{l}\text { Conc. formic acid hydrolysis at } 60^{\circ} \mathrm{C} \text { for } 6 \mathrm{~h} \text { followed by } 15 \% \text { aq. ammonia } \\
\text { delignification at } 60^{\circ} \mathrm{C} \text { for } 12 \mathrm{~h}\end{array}$ & 0.19 & 30 & 62.7 & 77.3 & Zhang et al. (2010) \\
\hline Corn cobs & $\begin{array}{l}2 \text { wt.\% sulfuric acid at } 121^{\circ} \mathrm{C} \text { for } 45 \text { min followed by } 2 \text { wt.\% sodium } \\
\text { hydroxide at } 80^{\circ} \mathrm{C} \text { for } 6 \mathrm{~h} \text {. }\end{array}$ & 0.25 & 22.8 & 84.7 & 79 & Zhang et al. (2010) \\
\hline Coffee residue & Popping pretreatment at a pressure of $1.47 \mathrm{MPa}$ for $10 \mathrm{~min}$ & 0.10 & $2.23^{\mathrm{g}}$ & 15.3 & 87.2 & Choi et al., 2012 \\
\hline $\begin{array}{l}\text { Oil palm empty fruit } \\
\text { bunches }\end{array}$ & $21 \%$ ammonia at $60{ }^{\circ} \mathrm{C}$ for $12 \mathrm{~h}$ & 0.05 & 60 & 18.6 & 65.6 & Jung et al., 2012 \\
\hline Olive tree pruning & $1 \% \mathrm{H}_{2} \mathrm{SO}_{4}$ hydrolysis at $180^{\circ} \mathrm{C}$ for $10 \mathrm{~min}$ & 0.225 & 15 & 24.9 & 38 & $\begin{array}{l}\text { Manzanares et al., } \\
2011\end{array}$ \\
\hline Eucalyptus globulus & Autohydrolysis at $230^{\circ} \mathrm{C}$ & 0.10 & 6.2 & 26.7 & 77.7 & Romaní et al. 2010 \\
\hline Eucalyptus globulus & Autohydrolysis at $230^{\circ} \mathrm{C}$ & 0.25 & 16 & 67.4 & 91.1 & Romaní et al., 2012 \\
\hline Eucalyptus globulus & Delignification with $60 \%$ ethanol & 0.10 & 20 & 35 & - & Muñoz et al., 2011 \\
\hline Eucalyptus grandis & $1.2 \% \mathrm{H}_{2} \mathrm{SO}_{4}$ hydrolysis at $121^{\circ} \mathrm{C}$ for $45 \mathrm{~min}$ & 0.20 & 30 & 28.7 & - & Silva et al., 2011 \\
\hline Paper bark tree & Subcritical water at $180^{\circ} \mathrm{C}$ for $30 \mathrm{~min}$ & 0.15 & 16 & 43.7 & 91.3 & This work \\
\hline Paper bark tree & Subcritical water at $180^{\circ} \mathrm{C}$ for $30 \mathrm{~min}$ & 0.25 & 10 & 54.6 & 70 & This work \\
\hline Paper bark tree & Subcritical water at $180^{\circ} \mathrm{C}$ for $30 \mathrm{~min}$ & 0.25 & 16 & 62.3 & 81 & This work \\
\hline
\end{tabular}

a : solid loading.

b EL: enzyme loading.

${ }^{c} \mathrm{E}_{\max }$ : maximum ethanol concentration.

${ }^{\mathrm{d}} \mathrm{EC}_{\text {max }}$ : maximum ethanol yield.

e $0.7 \mathrm{~mL} / \mathrm{g}$ glucan of cellulase with activity $82.2 \mathrm{FPU} / \mathrm{mL}$

f $18.3 \mathrm{mg}$ protein/g glucan with activity $0.122 \mathrm{FPU} / \mathrm{mg}$ protein.

$\mathrm{g}$ not reported.

Eucalyptus grandis pretreated with acids, Silva et al. (2011) obtained an ethanol concentration of $28.7 \mathrm{~g} \mathrm{~L}^{-1}$ operating under $0.20 \mathrm{~g} \mathrm{~mL}^{-1}$ solid loading, but high enzyme loading (30 FPU g ${ }^{-1}$ ) was required. Muñoz et al. (2011) employed organosolv-delignified Eucalyptus wood to obtain substrates containing $84 \%$ cellulose, which was processed by SSF $\left(0.10 \mathrm{~g} \mathrm{~mL}^{-1}\right.$ solid and $20 \mathrm{FPU} \mathrm{g}^{-1}$ enzyme loadings) to reach ethanol concentration up to $35 \mathrm{~g} \mathrm{~L}^{-1}$, but some cellulose was lost in the pretreatment step. Zhang et al. (2010) reported that using a pretreated corncob first with acidic solutions and then under alkaline conditions, increasing the solids loading from $0.075 \mathrm{~g} \mathrm{~mL}^{-1}$ up to $0.19 \mathrm{~g} \mathrm{~mL}^{-1}$ caused a decrease of ethanol yield from $90 \%$ to $77 \%$. Similar result was reported when using hardwood pretreated with liquid hot water or by acid prehydrolysis, ethanol yield was significantly reduced as solid loading was increased from $0.09 \mathrm{~g} \mathrm{~mL}^{-1}$ to $0.23 \mathrm{~g} \mathrm{~mL}^{-1}$ (Manzanares et al., 2011). Romaní et al. (2012) reported high ethanol yield (91.1\%) and high ethanol concentration $\left(67.4 \mathrm{~g} \mathrm{~L}^{-1}\right)$ using $0.25 \mathrm{~g} \mathrm{~mL}^{-1}$ Eucalyptus globules after autohydrolysis treatment at high temperature $\left(230^{\circ} \mathrm{C}\right)$

This work implemented the environmentally friendly SCW pretreatment at mild temperature $\left(180^{\circ} \mathrm{C}\right)$ without utilization of chemicals. High ethanol concentration $\left(63.2 \mathrm{~g} \mathrm{~L}^{-1}\right)$ with high ethanol yield $(80.9 \%)$ was obtained at $0.25 \mathrm{~g} \mathrm{~mL}^{-1}$ solid loading. Simultaneous high ethanol concentration $\left(43.7 \mathrm{~g} \mathrm{~L}^{-1}\right)$ and yield $(91.25 \%)$ can be obtained at $0.15 \mathrm{~g} \mathrm{~mL}^{-1}$ solid loading. These values meet the requirements for economically viable production of ethanol from PBT lignocelluloses on an industrial scale.

\section{Conclusion}

The results of this study showed that Melaleuca leucadendron shedding bark has high glucan component and confirmed that SCW pretreated PBT biomass implemented in SSF mode is suitable for economically feasible production of bioethanol. Optimization of the process resulting in the identification of operational conditions (pretreatment temperature $180^{\circ} \mathrm{C}$; high solid loading $0.15-$ $0.25 \mathrm{~g} \mathrm{~mL}^{-1}$ and enzyme loading $16 \mathrm{FPU} \mathrm{g}^{-1}$ glucan) enabling simultaneously high ethanol concentration $\left(43.7 \mathrm{~g} \mathrm{~L}^{-1}\right.$ to $63.2 \mathrm{~g} \mathrm{~L}^{-1}$ ) and ethanol yield (91.25-80.9\%).

\section{Acknowledgements}

The authors would like to acknowledge the National Science Council of Taiwan (NSC100-2623-E-011-001-ET) and National Taiwan University of Science and Technology $(100 \mathrm{H} 451403)$ for financing this work.

\section{Appendix A. Supplementary data}

Supplementary data associated with this article can be found, in the online version, at http://dx.doi.org/10.1016/j.biortech.2013.02. 097.

\section{References}

Alenezi, R., Leeke, G.A., Santos, R.C.D., Khan, A.R., 2009. Hydrolysis kinetics of sunflower oil under subcritical water conditions. Chem. Eng. Res. Des. 87, 867873.

Alfani, F., Gallifuoco, A., Saporosi, A., Spera, A., Cantarella, M., 2000. Comparison of SHF and SSF processes for the bioconversion of steam-exploded wheat straw. J. Ind. Microbiol. Biotechnol. 25, 184-192.

Carolina, C.M., Arturo, J.G., Mahmoud, E.H., 2011. A comparison of pretreatment methods for bioethanol production from lignocellulosic materials. Process. Saf. Environ. 90, 189-202.

Chen, H., Xu, J., Li, Z., 2007. Temperature cycling to improve the ethanol production with solid state simultaneous saccharification and fermentation. Appl. Biochem. Microbiol. 43, 57-60.

Choi, I.S., Wi, S.G., Kim, S.B., Bae, H.J., 2012. Conversion of coffee residue waste into bioethanol with using popping pretreatment. Bioresour. Technol. 125, 132-137. 
Fenning, T.M., Walter, C., Gartland, K.M.A., 2008. Forest biotech and climate change. Nat. Biotechnol. 26, 615-617.

García-Aparicio, M.P., Oliva, J.M., Manzanares, P., Ballesteros, M., Ballesteros, I., González, A., Negro, M.J., 2011. Second-generation ethanol production from steam exploded barley straw by Kluyveromyces marxianus CECT 10875. Fuel 90, 1624-1630.

Garrote, G., Dominguez, H., Parajo, J.C., 1999. Mild autohydrolysis: and environmentally friendly technology for xylooligosaccharide production from wood. J. Chem. Technol. Biotechnol. 74, 1101-1109.

Geary, T.F., Woodall, S.L., 1990. Melaleuca quinquenervia (Cav.) S. T. Blake melaleuca, in: Burns, R.M., Honkala, B.H., Silvics of North America, Vol. 2. Hardwoods, Agric. Hand b. 654, U.S. Department of Agriculture, Forest Service, Washington, DC, pp. 461-465.

Geiger, R.K., 1981. Proceedings of melaleuca symposium, Fort Myers, FL, September 23-24, 1980. Florida Division of Forestry, Tallahassee, p. 140.

Guenther, E., 1950. The essential oil. REK Publishing Company, Florida, Vol. IV, pp. $602-615$.

Hendriks, A.T.W.M., Zeeman, G., 2009. Pretreatments to enhance the digestibility of lignocellulosic biomass. Bioresour. Technol. 100, 10-18.

Hoyer, K., Galbe, M., Zacchi, G., 2009. Production of fuel ethanol from softwood by simultaneous saccharification and fermentation at high dry matter content. J. Chem. Technol. Biotechnol. 84, 570-577.

Jung, Y.H., Kim, I.J., Han, J.I., Choi, I.G., Kim, K.H., 2012. Aqueous ammonia pretreatment of oil palm empty fruit bunches for ethanol production. Bioresour. Technol. 102, 9806-9809.

Kruse, A., Dinjus, E., 2007. Hot compressed water as reaction medium and reactant properties and synthesis reactions. J. Supercritical Fluids 39, 362-380.

Lee, S.H., Doherty, T.V., Linhardt, R.J., Dordick, J.S., 2009. Ionic liquid-mediated selective extraction of lignin from wood leading to enhanced enzymatic cellulose hydrolysis. Biotechnol. Bioeng. 102, 1368-1376.

Liu, S., 2010. Woody biomass: Niche position as a source of sustainable renewable chemicals and energy and kinetics of hot-water extraction/hydrolysis. Biotechnol. Adv. 28, 563-582.

Lu, Y., Wang, Y., Xu, G., Chu, J., Zhuang, Y., Zhang, S., 2010. Influence of high solid concentration on enzymatic hydrolysis and fermentation of steam-exploded corn stover biomass. Appl. Biochem. Biotechnol. 160, 360-369.

Lu, X., Saka, S., 2010. A hydrolysis of Japanese beech by batch and semi-flow water under subcritical temperatures and pressures. Biomass Bioenerg. 34, 10891097.

Manzanares, P., Negro, M.J., Oliva, J.M., Sáez, F., Ballesteros, I., Ballesteros, M., 2011. Different process configurations for bioethanol production from pretreated olive pruning biomass. J Chem. Technol. Biotechnol. 86, 881-887.

Mosier, N.S., Hendrickson, R., Brewer, M., Ho, N., Sedlak, M., Dreshel, R., Welch, G., Dien, B.S., Aden, A., Ladisch, M.R., 2005. Industrial scale-up of pH controlled liquid hot water pretreatment of corn fiber for fuel ethanol production. Appl. Biochem. Biotechnol. 125, 77-79.
Muñoz, C., Baeza, J., Freer, J., Mendoça, R.T., 2011. Bioethanol production from tension and opposite wood of Eucalyptus globulus using organosolv pretreatment and simultaneous saccharification and fermentation. J. Ind. Microbiol. Biotechnol. 38, 1861-1866.

Pessani, N.K., Atiyeh, H.K., Wilkins, M.R., Bellmer, D.D., Banat, I.M., 2011. Simultaneous saccharification and fermentation of Kanlow switchgrass by thermotolerant Kluyveromyces marxianus IMB3: The effect of enzyme loading, temperature and higher solid loadings. Bioresour. Technol. 102, 10618-10624.

Renewable fuel Association, 2010. Ethanol Industry Outlook: Climate of Opportunity, Available at: http://ethanolrfa.org/page//objects/pdf/outlook/ RFAoutlook2010_fin.pdf?nocdn=1.

Renewable fuel Association, 2012. Ethanol Industry Outlook: Accelerating Industry Innovation. Available at: http://ethanolrfa.3cdn.net/d4ad995ffb7ae8fbfe_ 1 vm62ypzd.pdf.

Romaní, A., Garrote, G., Alonso, J.L., Parajó, J.C., 2010. Bioethanol production from hydrothermally pretreated Eucalyptus globulus wood. Bioresour. Technol. 101, 8706-8712.

Romaní, A., Garrote, G., Parajó, J.C., 2012. Bioethanol production from autohydrolyzed Eucalyptus globules by Simultaneous Saccharification and Fermentation operating at high solids loading. Fuel 94, 305-312.

Sassner, P., Galbe, M., Zacchi, G., 2006. Bioethanol production based on simultaneous saccharification and fermentation of steam-pretreated Salix at high dry-matter content. Enzyme Microb. Technol. 39, 756-762.

Shill, K., Padmanabhan, S., Xin, Q., Prausnitz, J.M., Clark, D.S., Blanch, H.W., 2011. Ionic liquid pretreatment of cellulosic biomass: Enzymatic hydrolysis and ionic liquid recycle. Biotechnol. Bioeng. 108, 511-520.

Silva, N.L.C., Betancur, G.J.V., Vasquez, M.P., Gomes, E.B., Pereira, N., 2011. Ethanol production from residual wood chips of cellulose industry: acid pretreatment investigation, hemicellulosic hydrolysate fermentation, and remaining solid fraction fermentation by SSF process. Appl. Biochem. Biotechnol. 163, 928-936.

Sluiter, A., Hames, B., Ruiz, R., Scarlata, C., Sluiter, J., Templeton, D., Crocker, D., 2011. Determination of structural carbohydrates and lignin in biomass, NREL. Technical, Report NREL/TP-510-42618.

Valentine, S.V., 2011. Emerging symbiosis: Renewable energy and energy security. Renew. Sust. Energ. Rev. 15, 4572-4578.

Zhang, J., Chu, D., Huang, J., Yu, Z., Dai, G., Bao, J., 2010. Simultaneous saccharification and ethanol fermentation at high corn stover solids loading in a helical stirring bioreactor. Biotechnol. Bioeng. 105, 718-728.

Zhang, Y.H.P., Lynd, L.R., 2004. Review: Toward an Aggregated Understanding of Enzymatic Hydrolysis of Cellulose: Noncomplexed Cellulase Systems. Biotechnol. Bioeng. 88, 797-824.

Zhang, M., Wang, F., Sua, R., Qia, W., Hea, Z., 2010. Ethanol production from high dry matter corncob using fed-batch simultaneous saccharification and fermentation after combined pretreatment. Bioresour. Technol. 101, 4959-4964. 